\title{
Obituary
}

\section{Anthony Thwaite 23 June 1930-22 April 2021}

\author{
Paul Bennett \\ Society for Libyan Studies
}

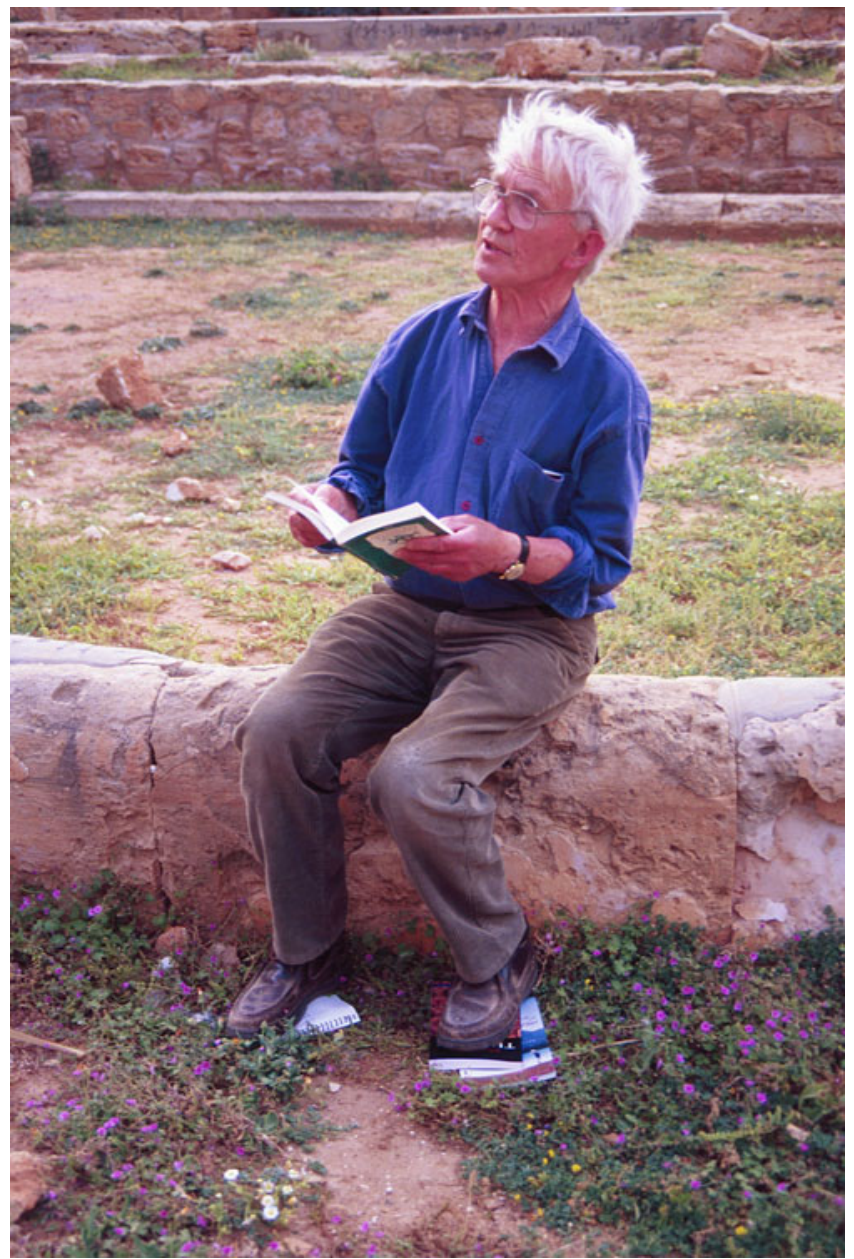

Figure 1. Anthony Thwaite in the theatre at Apollonia, reading his poetry to the archaeological team working at Euesperides, 10 April 2003.

Anthony Thwaite, the celebrated poet and critic, and less wellknown amateur archaeologist, passed away on 22 April 2021 at the age of 90 .

In the early 2000s Anthony joined the Society's Eusperides expedition, assisting the finds specialists and maintaining team spirit. Affectionately known to us as 'shebani' (the old man), he was greatly loved and respected by all the team, by Libyan colleagues, students from the universities of Benghazi and al-Baida who were being trained by us at that time, members of the Department staff and our friends in the Benghazi community. All who spent

Corresponding author: Paul Bennett, Email: paul@profpaulbennett.co.uk

Cite this article: Bennett P (2021). Anthony Thwaite 23 June 1930-22 April 2021. Libyan Studies 52, 9-10. https://doi.org/10.1017/lis.2021.19 time with him have treasured memories of outings in downtown Benghazi, or on more distant visits to Cyrene, Apollonia (Figure 1) and Tocra; of being spellbound by Anthony's stories of times gone by, of a Libya before Gaddafi.

It was evident to us that Anthony had a deep love for Libya, its people and their heritage, but few of us realized that our witty, charming 'shebani', who took such joy washing and handling pottery and other artefacts from the excavation, was in fact one of the great movers and shakers in post-war English literary life. Literary editor of The Listener, The New Statesman, co-editor of Encounter, Chair of the Booker Prize panel in 1986, producer at the $\mathrm{BBC}$, prolific author, reviewer, poet, traveller and lecturer, Anthony's friends included a who's who in British post-war literary circles, notably Philip Larkin, Geoffrey Hill, Ted Hughes, Paul Muldoon, Seamus Heaney and Andrew Motion. He was an exceptionally modest and engaging man, with a good word for everyone, a wonderful spinner of tales and an abiding interest in archaeology.

Born in Chester in 1930, when the war broke out in 1939, Anthony was evacuated by his parents to the US where he spent four years living with an aunt near Washington. He had memories of searching for civil war relics in Confederate trenches in Fairfax County, Virginia and later wrote:

\begin{abstract}
Ever since I was seven, I have been almost obsessively devoted to the past and the things of the past. On my seventh birthday, my favourite uncle gave to me a Roman silver denarius, and from that time on I became an antiquarian magpie.
\end{abstract}

Returning to England in 1944, he attended Kingswood School in Bath where he joined the archaeological society and later organised the excavation of an Anglo-Saxon cemetery. He fully intended to read archaeology at Oxford, but national service intervened and after basic training he was posted acting sergeant to the Royal Artillery garrison at al-Khums. Arriving there on his twentieth birthday, he soon discovered the nearby ruins of Septimius Severus's great city of Lepcis Magna. This reignited Anthony's fascination with archaeology, and over time, greatly increased his 'magpie' collection of potsherds.

On his return he accepted a place a Christ Church, Oxford to read English, publishing his first work in 1953. He married fellow student Ann Harrop in 1955 and although he was accepted for a traineeship by the BBC, instead he took a two-year lectureship to teach literature in Tokyo. Poems written in Japan appear in his Letters from Tokyo (1987).

In 1957 he joined the BBC becoming acting head of the Far Eastern Service. In the same year he published his first book of poems, Home Truths. He was later transferred to the talks department at Broadcasting House and in 1962 became the literary editor of The Listener. 
In 1965, Anthony, Ann and their young family took leave from the BBC and moved to Libya to take up a two-year appointment as assistant professor of English at the University of Libya in Benghazi. This was the Libya of King Idris and the British Protectorate that Anthony so vividly remembered, entertaining us with witty and endearing stories of teaching at the university, of the places he visited and the people he met. His deep and growing love of the country and its people is recounted in his book The Deserts of Hesperides, first published in 1969 and subsequently reprinted by the Society's Silphium Press in 2015.

He took part in the last season of an emergency excavation on the foreshore of Tocra, where coastal erosion had exposed part a votive deposit of whole pots and terra cottas belonging to a sanctuary dedicated to Demeter and Kore. The finds, from many parts of the Greek world dating from the last quarter of the seventh century $\mathrm{BC}$ and the third quarter of the sixth, together with his other experiences of Libyan landscapes, archaeological sites and Libyan society, fed Anthony's passion as an amateur archaeologist and poet. When he returned to the UK in 1967, three collections of poems, The Stones of Emptiness (1967), Inscriptions (1973) and New Confessions (1974), revealed how forcefully religion (Anthony and Ann were committed churchgoers throughout their married lives) and archaeology (particularly Libyan heritage) had come to shape his creative life.

On a weekend visit to Cyrene with Anthony, the team stopped off at the site of Balagrae, famous for the remains of a Sanctuary of Asklepios (a place of healing) dating from the fourth century $\mathrm{BC}$ and for the later site of Balagrae mentioned in the letters of Synesius, Bishop of Ptolemais (c. AD 370-413). I can remember being struck by the depth of Anthony's knowledge of Synesius, his life and the troubled times he lived in, when the Pentapolis was under deadly threat from hostile Libyan tribes and economic, social and military decline in the aftermath of natural catastrophe. I was unaware at the time of Anthony's poem, 'The Letters of Synesius', depicting a reluctant bishop trying to defend the dying Christian community and failing to understand the design of a world tumbling towards destruction. His poem, a meditation on Synesius, was not mentioned, but his interest in the bishop and the decline of the Pentapolis was well-informed and undiminished.

In 1973 the Thwaite family moved to Norfolk and Anthony became co-editor of Encounter for the next twelve years. In
1990 he was appointed OBE in recognition of his own talents and his contribution to the national literary scene.

Anthony's later books included a substantial Collected Poems (2007), Late Poems (2010) and Going Out (2015). Many of his poems dwell on Libya and its heritage, including 'Sigma', which he chose to read on Radio 4 when the BBC celebrated his ninetieth birthday last year.

\section{Sigma}

Unable to get on with anything,

Throwing out papers, fiddling with piled mess,

I pull a box of sherds out, stacked up here

Among the whole accumulation, less

Because I want to but because it's there -

A scattering of pottery I picked up

Among the Libyan middens I knew once,

And rake it over, chucking out here a cup-

Handle, broken, and a flaking rim:

And, in among it all, there's suddenly

This scrap that carries a graffito $-\sum$

A sigma, a scratched ess; and try to tell

Where it once fitted - as beginning or end,

As some abbreviated syllable,

Or sign of ownership, or just a scribble

Made on a day in $450 \mathrm{BC}$

By someone else who messed about like this,

Unable to get on with anything,

But made his mark for someone else to see.

(Selected Poems, Enitharmon Press, 1997)

Following his adventures with the Euesperides team, Anthony served on Council from 2007-2011 and was a regular attendee of Society functions, lectures and the AGM.

He will be greatly missed, but 'shebani' remains vibrant in the memory of all who rubbed shoulders with him in Libya. A witty, charming companion with a phenomenally good memory, he leaves a tremendous legacy of prose and poetry of rare clarity, much of it inspired by archaeology and time spent in Libya.

Anthony Simon Thwaite, poet, critic, amateur archaeologist and self-confessed 'magpie', born 23 June 1930; died 22 April 2021, is survived by his wife Ann and daughters Emily, Caroline, Lucy and Alice. 